\title{
Morphological changes of Microcystis aeruginosa colonies in culture
}

\author{
Qianqian SUN, ${ }^{1}$ Wei ZHU, ${ }^{1,2}$ Ming LI, ${ }^{1,3,4 *}$ Xiao TAN ${ }^{1}$
}

${ }^{1}$ College of Environment, Hohai University, No. 1 Xikang Road, Nanjing 210098, PR China; ${ }^{2}$ National Engineering Research Center of Water Resources Efficient Utilization and Engineering Safety, Hohai University, Nanjing 210098, China; ${ }^{3}$ College of Resources and Environment, Northwest Agriculture and Forestry University, Yangling 712100, China; ${ }^{4}$ Key Laboratory of Plant Nutrition and the Agri-environment in Northwest China, Ministry of Agriculture, China

*Corresponding author: lileaf@163.com

\begin{abstract}
We investigated the changes in the morphology, genetics and photosynthetic characteristics of Microcystis aeruginosa colonies during two months of cultivation. The colonies were collected in Lake Taihu, kept under $25^{\circ} \mathrm{C}$ on a $12 \mathrm{~h}: 12 \mathrm{~h}$ light/dark cycle at a light density of about $45 \mu \mathrm{mol} \mathrm{m} \mathrm{m}^{-2} \mathrm{~s}^{-1}$. M. novacekii-type colonies were detected on the $10^{\text {th }}$ day and their percentage of the population tended to increase until the $60^{\text {th }}$ day. With $\mathrm{M}$. novacekii-like colonies increased, the proportion of $\mathrm{M}$. aeruginosa colonies decreased and reached almost zero by the end of the experiment. M. novacekii-like colony size $\left(D_{50}\right.$; this value indicates that particles below $D_{50}$ accounts for $50 \%$ ) was greater than $500 \mu \mathrm{m}$ when these colonies first appeared and was similar to that of $\mathrm{M}$. aeruginosa in the experiment. No differences in cell size were found between these two Microcystis morphotypes either collected from Lake Taihu or cultured in the labo-

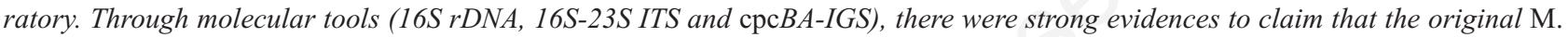
aeruginosa colonies isolated from Lake Taihu and the later M. novacekii-like colonies in our cultures were the same species. We suggest that $\mathrm{M}$. aeruginosa colonies consistently changed their colonial morphology to that of a typical M. novacekii.
\end{abstract}

Key words: Microcystis aeruginosa, Microcystis novacekii, morphospecies, morphological changes, seasonal succession.

Received: April 2015. Accepted: June 2015.

\section{INTRODUCTION}

Frequent cyanobacterial blooms cause serious ecological and environmental problems (Paerl et al., 2001; Otten and Paerl, 2011). Microcystis spp. is one of the most widely distributed and harmful bloom-forming cyanobacteria (Cao et al., 2005; Sivonen and Jones, 1999). Microcystis form large irregular or quasi-spherical colonies in freshwater ecosystems and several species (e.g., Microcystis aeruginosa, Microcystis wesenbergii, Microcystis ichthyoblabe and Microcystis novacekii, etc.) have been identified based on their morphological characteristics (Desikachary, 1959, Komárek, 1991; Komárek and Komárková, 2002).

Seasonal succession of Microcystis morphospecies has been reported in varying inland waters. These inland waters included Lake Suwa (Park, 1993), Lake Biwa (Ozawa et al., 2005), an eutrophic pond in Japan (Yamamoto et al., 2009), Lake Chaohu (Jia et al., 2011), and Lake Taihu (Li et al., 2013b). The dynamics of the seasonal succession of Microcystis morphospecies are important in understanding the occurrence of Microcystis blooms and in evaluating the risk of toxic microcystins, because growth and toxin production vary among morphospecies (Watanabe et al., 1988, 1989; Imai et al., 2009).

Our previous study (Li et al., 2014a) argued that the seasonal succession of Microcystis morphospecies could be explained by colonial morphological changes induced by mucilage solubilization. Patterns of colonial morphological changes were summarized as $M$. ichthyoblabe, $M$. wesenbergii and M. aeruginosa successively, which was similar to the succession patterns of Microcystis noted in field studies. Merely, the morphological variation after $M$. aeruginosa needs further investigation. Moreover, the results of our previous study were obtained after Microcystis colonies were soaked in deionized water in darkness at $4^{\circ} \mathrm{C}$ (Li et al., 2014a), which differed from common culture conditions and the data were not conclusive. Thus, it was necessary to investigate the morphological changes of Microcystis in culture. Otsuka et al. (2000) reported that the morphology of $M$. wesenbergii changed to that of M. aeruginosa under culture condition. Nevertheless, the knowledge of morphological changes of Microcystis colonies was still insufficient.

Phenotypic plasticity of Microcystis has been well reported (Cao and Yang, 2010; Yang et al., 2008). It is well known that Microcystis colonies usually lose their characteristic features, disaggregate to single cells after long-term culture (Zhang et al., 2007). Conversely, it has been found that specific genotypes of freshwater singlecell Synechococcus can form microcolonies, transitional forms towards colonial cyanobacteria, as a fast response to UV radiation (Callieri et al., 2011, 2012). Several re- 
searchers (Yang et al., 2005; Shen et al., 2011) tried to induce colony formation of unicellular Microcystis by changing various factors under culture conditions. Many biotic and abiotic factors (e.g., zooplankton, bacteria, light, temperature, nutrient level) were reported effective in inducing colony formation of Microcystis (Yang et al., 2008; Shen et al., 2011; Yang and Kong, 2013; Li et al., 2013c). However, the morphology of induced colonies was still different from that of Microcystis colonies in field. The investigation of the morphological changes of Microcystis under culture conditions would be helpful to understand the difference in colonial morphology between colonies induced under culture conditions and in the field.

Combined with the descriptions above, it is necessary to investigate the morphological changes of $M$. aeruginosa under culture condition. In the current study, $M$. aeruginosa colonies collected in Lake Taihu were cultured. Both the morphology and photosynthetic characteristics of Microcystis were investigated. The photosynthetic characteristics were analyzed to check whether cells were in normal activity. If so, the morphological changes occurred in the cultures would be not induced by stress.

\section{METHODS}

\section{Colony collection and culture experiment}

Microcystis colonies were collected in Meiliang Bay $\left(31^{\circ} 30.06^{\prime} \mathrm{N} ; 120^{\circ} 10.97^{\prime} \mathrm{E}\right)$ in Lake Taihu, southeast China, on $20^{\text {th }}$ October 2013 (water temperature was $18^{\circ} \mathrm{C}$, wind speed was less than $3 \mathrm{~m} \mathrm{~s}^{-1}$ ) when M. aeruginosa was the dominant Microcystis morphospecies (Li et al., 2013b). Water at the depth of $30 \mathrm{~cm}$ below lake surface was collected by a sampling barrel and then a phytoplankton net ( $63 \mu \mathrm{m}$ mesh size) was used to entrap the colonies. The collected colonies were put into $500-\mathrm{mL}$ plastic bottles and taken back to the laboratory immediately.

Colonies were dispersed by BG-11 culture medium. Each colony was observed under a CX31 optical microscope. Only colonies with the morphological characteristics of $M$. aeruginosa were collected for the culture experiment. The selected colonies were cultured in triplicate in $75 \mathrm{~mL}$ BG-11 medium in $100-\mathrm{mL}$ conical flasks at $25^{\circ} \mathrm{C}$ under a $12 \mathrm{~h}: 12 \mathrm{~h} \mathrm{~L} / \mathrm{D}$ cycle with a photon flux density of about $45 \mu \mathrm{mol} \mathrm{m}^{-2} \mathrm{~s}^{-1}$ provided by daylight fluorescent lamps. Cell density was counted after incubation following the methods described by Li et al., (2013c) and the initial cell density was $1.3 \pm 0.2 \times 10^{5}$ cells $\mathrm{mL}^{-1}$.

\section{Analysis of colonial morphology and colony size}

The morphology of Microcystis including colonial morphology, colony size, and cell size was analyzed every 10 days. Each sample was shaken gently and thoroughly and a $5-\mathrm{mL}$ sample was drawn out to analyze colonial morphology. Microphotographs were taken using a CX31 optical microscope (100×) equipped with an Olympus C5050 digital camera to determine the morphological composition and the colony size. Cell size was also analysed. Colonies were divided into M. aeruginosa and other morphotypes based on the colonial morphological characteristics listed in Tab. 1 referring to Watanabe (1996) and Komarek and Anagnostidis (1999).

The photomicrographs were analyzed using UTHSCSA Image Tool Version 3.00 software (Department of Dental Diagnostic Science, University of Texas Health Science Center, San Antonio, TX, USA) to measure colony size. About 100 colonies of each sample were analyzed each time. As colonies of different morphospecies were irregular, the longest axis (the longest length of each colony) and the shortest axis (the longest length that is perpendicular to the longest axis) of each colony was measured. The colony diameter $(\mu \mathrm{m})$ was estimated as:

$$
R=\sqrt{R_{1} \times R_{2}}
$$

where $R_{1}$ is the longest axis, and $R_{2}$ is the shortest axis.

Biovolumes of measured colonies were calculated from colony size using a sphere volume calculation formula. The percentages of different Microcystis morphotypes and $\mathrm{D}_{50}$ (the colony size at which $50 \%$ of the total mass of the particles was smaller than this size; Li et al., 2014b) were calculated using biovolume.

Tab. 1. Colony characteristics of $M$. aeruginosa and other morphotypes.

\begin{tabular}{ll} 
Morphospecies & Colony characteristics \\
M. aeruginosa & $\begin{array}{l}\text { Colonies are more or less firm, more or less spherical, elongate, lobate, or reticulated. Margin of colony is indistinct. Cells } \\
\text { are somewhat densely and irregularly agglomerated }\end{array}$ \\
M. novacekii & $\begin{array}{l}\text { Colonies are microscopic, composed of subcolonies, almost spherical, no lobate, composed of tightly aggregated cells and a } \\
\text { thick surrounding gelatinous substance }\end{array}$ \\
\hline M. ichthyoblabe & $\begin{array}{l}\text { The distribution of cells in colonies is homogeneous, irregular, or sponge-like, and the margin of the colony is regular and } \\
\text { invisible without treatment }\end{array}$ \\
\hline
\end{tabular}

According to Watanabe (1996) and Komarek and Anagnostidis (1999). 


\section{Cell size analysis}

After microphotographs of colonies were taken, about 10 Microcystis colonies (with the same colonial morphological characteristics) from the $5-\mathrm{mL}$ sample were randomly isolated. Colonies with the same morphological characteristics were put together and disaggregated using the alkaline hydrolysis process described by Joung et al., (2006). After that, the microphotographs of unicellular cells were taken using a CX31 optical microscope $(1000 \times)$ equipped with an Olympus C-5050 digital camera. UTHSCSA Image Tool Version 3.00 software was used to analyze the cell diameter. The diameters of 200 cells were measured and the maximum, minimum, and average diameters of different morphotypes were calculated.

\section{Photosynthetic parameters}

The photosynthetic characteristics of Microcystis were analyzed by Phyto-PAM (Walz, Effeltrich, Germany) to determine the activity of Microcystis colonies at the beginning and at the end of the experiment. Accurate $10 \mathrm{~mL}$ medium from each sample was taken and mixed, then a 3-mL mixed sample was taken for analysis. The sample was kept in the dark for $10 \mathrm{~min}$, then the $\mathrm{F}_{\mathrm{v}} / \mathrm{F}_{\mathrm{m}}$ (maximum quantum yield of PSII) and the rapid light curve (RLC) was determined. The three characteristic parameters of the RLC were analyzed: the slope of the curve in the lightlimiting region (a) that is proportional to the efficiency of PSII (Schreiber, 2004), the maximum electronic transport rate $\left(\mathrm{ETR}_{\max }\right)$, which determines the maximum photosynthetic capacity of phytoplankton (Schreiber, 2004), and the saturating irradiance $\left(\mathrm{E}_{\mathrm{k}}\right)$ that represents the capacity of phytoplankton to tolerate short-term changes in light (Ralph and Gademann, 2005).

\section{PCR amplification and sequencing}

DNA for polymerase chain reaction (PCR) templates was extracted from $M$. aeruginosa colonies at the beginning and $M$. novacekii-like colonies at the end of the experiment by using the modified procedure (Zhou et al., 1996). Microcystis pellets were dispersed in $0.8 \mathrm{~mL}$ extraction buffer $(1.5 \mathrm{M} \mathrm{NaCl}, 1 \% \mathrm{CTAB}, 100 \mathrm{mM}$ Tris-
$\left.\mathrm{HCl}, 100 \mathrm{mM} \mathrm{Na} \mathrm{EDTA}, 100 \mathrm{mM} \mathrm{Na} \mathrm{PO}_{3}, \mathrm{pH} 0.8\right)$ and $20 \mu \mathrm{L}$ proteinase $\mathrm{K}\left(30 \mathrm{mg} \mathrm{mL}^{-1}\right)$, incubated at $37^{\circ} \mathrm{C}$ for $30 \mathrm{~min}$. Thereafter, $480 \mu \mathrm{L} 20 \% \mathrm{SDS}$ was added to each sample, which was then incubated at $65^{\circ} \mathrm{C}$ for $1 \mathrm{~h}$. Samples were extracted using phenol-choroform-isoamyl (25:24:1) and choroform-isoamyl (24:1) successively. Centrifuged at $8000 \times \mathrm{g}$ for $5 \mathrm{~min}$, the supernatant was moved to new tubes. Afterwards, $0.6 \mathrm{~mL} 100 \%$ isopropyl alcohol was added to purify the DNA sample. Centrifuged at $16,000 \times \mathrm{g}$ for $20 \mathrm{~min}$, the DNA sample was then rinsed with $70 \%$ ethanol. Each DNA sample was dried and dissolved in $100 \mu \mathrm{L}$ TE. The quantity and quality of DNA were determined by Nanodrop-2000.

Six pairs of primers were used for amplification and sequencing of all samples. The reactions were performed in a volume of $50 \mu \mathrm{L}$, containing $25 \mu \mathrm{L} 2 \times$ mixture buffer (Bioteke, Beijing, China), $2 \mu \mathrm{L}$ DNA (20 ng $\left.\mu \mathrm{L}^{-1}\right), 1.2 \mu \mathrm{L}$ Forward primer $(10 \mu \mathrm{M}), 1.2 \mu \mathrm{L}$ Reverse primer $(10 \mu \mathrm{M})$ and $20.6 \mu \mathrm{L} \mathrm{ddH_{2 }} \mathrm{O}$. The amplification program was set at $94^{\circ} \mathrm{C}$ for $5 \mathrm{~min}$, followed by 34 cycles of $94^{\circ} \mathrm{C}$ for 50 $\mathrm{s}, 50^{\circ} \mathrm{C}$ for $50 \mathrm{se}$ (MSR1, MSR2, MSR3 and ITS) or $52^{\circ} \mathrm{C}$ for $50 \mathrm{~s}$ ( $c p c \mathrm{BA}-\mathrm{IGS})$, and $72^{\circ} \mathrm{C}$ for $60 \mathrm{~s}$ followed by a final extension at $72^{\circ} \mathrm{C}$ for $10 \mathrm{~min}$. The amplified products were purified by a Gel Recovery Purification Kit (AxyPrep $^{\mathrm{TM}}$, Union City, CA, USA) and sequenced in Shanghai Sunny Biotechnology Co., Ltd.

Tab. 2 shows the primers applied in the current study which were cited by Otsuka et al., $(1998,1999$ a) and Neilan et al., (1995). MSR1, MSR2, MSR3 and $c p c B A-$ IGS were used for amplification and sequencing, ITS (A) for 16S-23S ITS amplification, ITS (S) for 16S-23S ITS sequencing.

\section{Alignment and phylogenetic analyses}

Using CLUSTAL X 2.0, we aligned 16S rDNA sequences isolated in this study with those of 9 reference strains for which morphospecies classification appears reliable (Otsuka et al., 1998). We similarly aligned 16S-23S ITS isolated in this study with those of 8 reference strains from Otsuka et al. (1999a) and cpcBA-IGS sequences with those of 4 reference strains from Wu et al. (2007) and 3 from the NCBI GenBank database. Maximum like-

Tab. 2. List of six pairs of primers for amplification and sequencing in Microcystis.

\begin{tabular}{|c|c|c|c|}
\hline Primer & For sequence $\left(5^{\prime}-3^{\prime}\right)$ & Rev sequence (5'-3') & Reference \\
\hline MSR1 & TTGATCCTGGCTCAGGATGA & GTCGTTAAGCAACCTGATTTG & Otsuka et al., 1998 \\
\hline MSR2 & CGGTAATACGGGGGAGGCAA & CCAACATCTCACGACACGAG & Otsuka et al., 1998 \\
\hline MSR3 & CTGGTGAAAGCTGGGGGTGC & GGTTACCTTGTTACGACTTC & Otsuka et al., 1998 \\
\hline ITS(A) & TCAGGTTGCTTAACGACCTA & (G/T)TTCGCTCGCC(A/G)CTAC & Otsuka et al., 1999 \\
\hline $\operatorname{ITS}(\mathrm{S})$ & CCAGTGAAGTCGTAACAAGG & GGGTT(T/G/C)CCCCATTCGG & Otsuka et al., 1999 \\
\hline$c p c \mathrm{BA}-\mathrm{IGS}$ & GGCTGCTTGTTTACGCGACA & CCAGTACCACCAGCAACTAA & Neilan et al., 1995 \\
\hline
\end{tabular}


lihood tree of phylogeny analysis was constructed by software MEGA 5.0 (Tamura et al., 2011), with the parameters being bootstrapped for 1000 replications.

\section{RESULTS}

\section{Morphological variability of colonies in culture}

Most of the colonies maintained the morphological characteristics of M. aeruginosa (Fig. 1a) for 10 days. Then, some colonies showed morphological variations (Fig. 1b), which gradually dispersed into small subcolonies with cells aggregated tightly. Thirty days later, the colonies were discontinuously elongated and resembled the morphotype of M. novacekii (Fig. 1c). After the first 60 days, the colonies became M. novacekii-like, which composed of small and firm subcolonies (Fig. 1d). In addition, some of these colonies were surrounded by thick, refractive, gelatinous substance that is characteristic of M. novacekii. After 65 days, the aggregation of cells in subcolonies became soft and the colonies gradually began to disperse to single cells (Fig. 1e). Nevertheless, some M. aeruginosa colonies had became homogeneous or sponge-like that is the characteristic of M. ichthyoblabe (Fig. 1f).

The composition of Microcystis morphotype during the experiment changed greatly over time (Fig. 2). Samples were dominated by $M$. aeruginosa in the first 30 days. The percentage of $M$. aeruginosa decreased throughout the culture, and became $<50 \%$ after 40 days. Meanwhile, the proportion of the intermediate morph between $M$. aeruginosa and M. novacekii also changed, increasing from 0 to $48 \%$ in the first 40 days. Subsequently, M. novacekii-like colonies dominated from the $50^{\text {th }}$ to $60^{\text {th }}$ day evidently. And some M. ichthyoblabe-like colonies that were irregular or sponge-like existed throughout the experiment, but even the highest proportion of these colonies was much smaller than that of $M$. novacekii-like colonies on the $60^{\text {th }}$ day.

\section{Colony size of Microcystis}

When M. novacekii-like colonies appeared on the $10^{\text {th }}$ day, the $\mathrm{D}_{50}$ value of them was more than $500 \mu \mathrm{m}$, which was similar to that of M. aeruginosa colonies (Fig. 3). From then on, the size of $M$. novacekii-like colonies was always larger than that of $M$. aeruginosa along with the increase of proportion of $M$. novacekii-like colonies.

\section{Photosynthetic activity of Microcystis}

To characterize the photosynthetic characteristics of the algae, $\mathrm{F}_{\mathrm{v}} / \mathrm{F}_{\mathrm{m}}$ and rapid light curve of these samples was tested at the beginning and the final phase (after culturing for 70 days). The $\mathrm{F}_{\mathrm{v}} / \mathrm{F}_{\mathrm{m}}$ of the initial Microcystis colonies
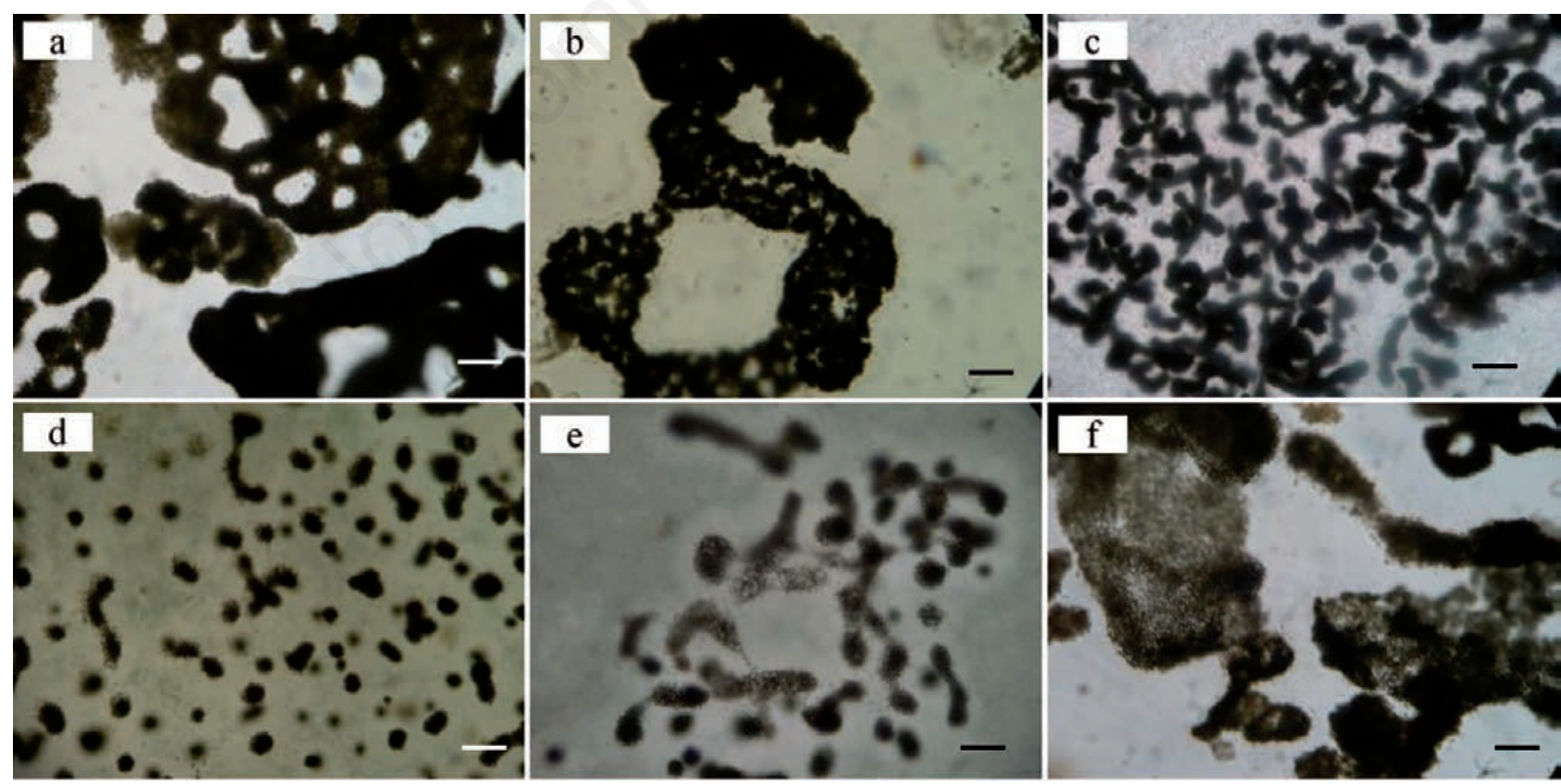

Fig. 1. Morphological variability of M. aeruginosa colonies in culture. a) A colony of M. aeruginosa which was picked out for culture experiment. b) A colony, which was cultured for 10 days, gradually dispersed into small subcolonies. c) A colony, which was cultured for 30 days, had elongated and discontinuous subcolonies. d) A colony, which was cultured for 60 days, was composed of small and firm subcolonies. e) A colony, which was cultured for 65 days, was less tightly arranged. F) A soft colony of $M$. aeruginosa on day 10 had sponge-like subcolonies. Scale bars: $100 \mu \mathrm{m}$. 
was 0.51 , and the value on the $70^{\text {th }}$ day was 0.24 . The slope of the linear section $(\alpha)$ was changed from 0.232 to 0.115 . The saturating irradiance $\left(\mathrm{E}_{\mathrm{k}}\right)$ varied from 352.6 to $773.5 \mu \mathrm{mol} \cdot \mathrm{m}^{-2} \cdot \mathrm{s}^{-1}$, and the maximum electron transport rate $\left(\mathrm{ETR}_{\max }\right)$ was from 81.6 to $88.8 \mu \mathrm{mol} \cdot \mathrm{m}^{-2} \cdot \mathrm{s}^{-1}$ (Fig. 4).

\section{Comparison of morphological characteristics}

According to the Microcystis colony characteristics described in Tab. 1, morphological characteristics (colony form, mucilage structure, cell distribution, colony size, and cell size) of different morphotypes were compared in detail (Tab. 3). All cells of these Microcystis morphospecies were spherical, and their diameters were very similar. Additionally, the mucilage of most colonies (except for some $M$. novacekii-like colonies) was invisible without treatment. In culture, the size of $M$. aeruginosa, $M$. novacekii-like colony as well as that of the intermediate morph was similar.

\section{S rDNA and 16S-23S ITS sequences}

M. aeruginosa colonies at the beginning and M. novacekii-like colonies on the $60^{\text {th }}$ day of our experiments were sequenced. The length of 16S rDNA and 16S-23S ITS were $1426 \mathrm{bp}$ and $360 \mathrm{bp}$, respectively. The phylogenetic tree based on the analysis of sequences of the $16 \mathrm{~S}$ rDNA and 16S-23S ITS showed that M. aeruginosa colonies at the beginning and $M$. novacekii-like colonies at the end of our experiments formed a defined cluster (Figs. 5 and 6), which located within the major Microcystis cluster.

\section{cpcBA-IGS sequences}

A length of $663 \mathrm{bp}$ of $c p c$ BA-IGS sequences was identified. Tab. 4 showed that the similarity of M. aeruginosa colonies at the beginning and $M$. novacekii-like colonies on the $60^{\text {th }}$ day of our experiments was 99.2 , which was higher than that of $M$. aeruginosa FACHB 936 and $M$. aeruginosa FACHB 912 (99.0\%) and that of M. novacekii UAM259 and M. novacekii UAM258 (96.0\%). This result suggested that $M$. aeruginosa colonies at the beginning and $M$. novacekii-like colonies at the end of our experiments be the same species.

\section{DISCUSSION}

Our experiment showed that $M$. novacekii-like colonies appeared after the $10^{\text {th }}$ day. The percentage of these colonies tended to increase until the $60^{\text {th }}$ day. Along with the increase of the percentage of these colonies, the percentage of M. aeruginosa decreased and reduced to almost zero by the end of the experiment (Figs. 1 and 2). Colony size $\left(\mathrm{D}_{50}\right)$ of $M$. novacekii-like colonies was $>500$ $\mu \mathrm{m}$ when they firstly appeared on the $10^{\text {th }}$ day which was

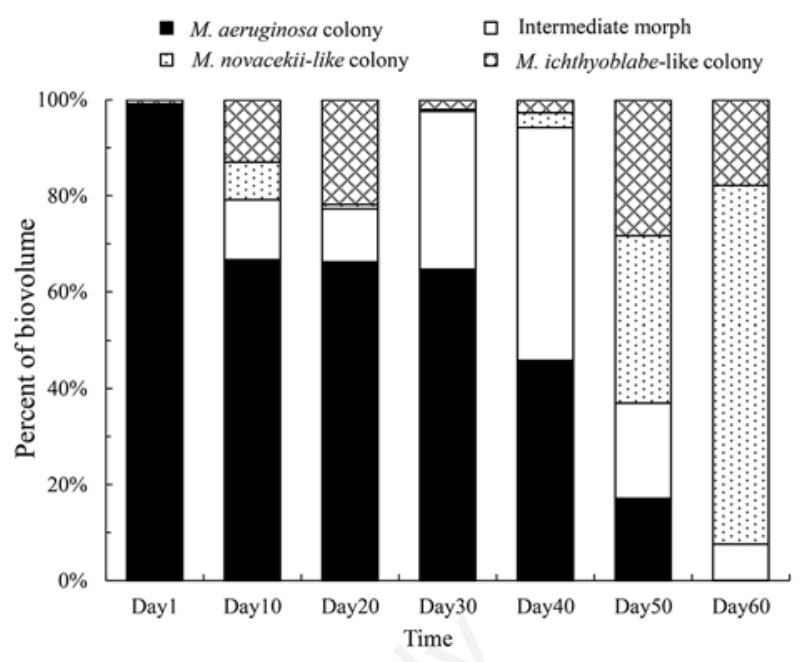

Fig. 2. Composition of Microcystis morphotypes in culture at different times.

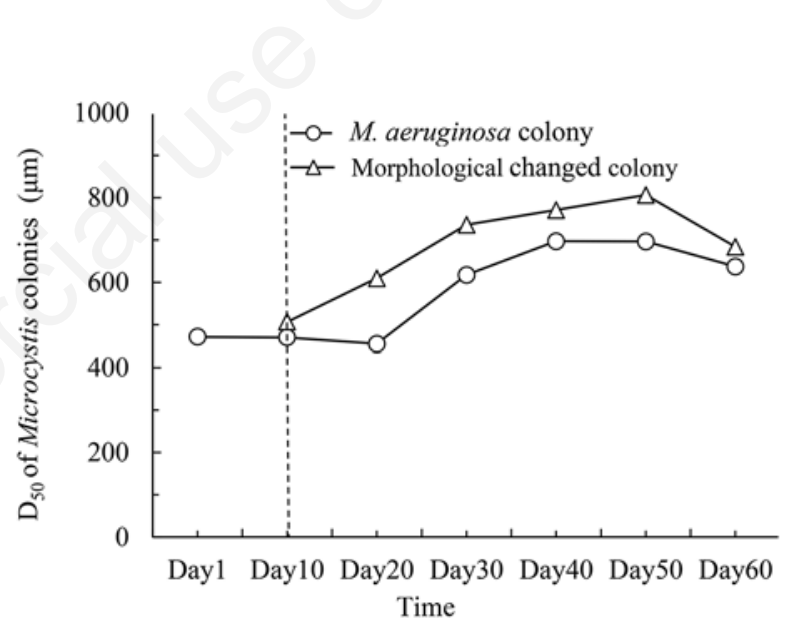

Fig. 3. The variation of $\mathrm{D}_{50}$ of $M$. aeruginosa and M. novacekiilike colonies in culture.

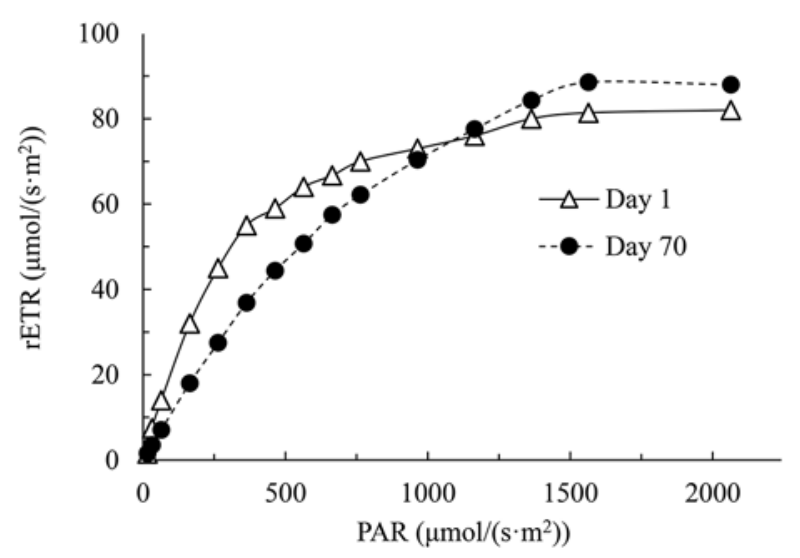

Fig. 4. Rapid light curve of Microcystis. The relative electron transport rate is plotted against the PAR irradiance $\left(\mu \mathrm{mol} \mathrm{m} \mathrm{m}^{-2} \mathrm{~s}^{-1}\right)$. 
similar to that of $M$. aeruginosa in culture. Our previous work showed that colonies with a maximum size of 100 $\mu \mathrm{m}$ formed after culturing Microcystis for 14 days under standard conditions (Li et al., 2013c). Yang and Kong (2012) also reported that the diameter of some colonies reached over $180 \mu \mathrm{m}$ during 50 days of culture. Even though the interval of morphological investigation in the current study was long and the first time $M$. novacekiitype colonies appeared was not precisely determined, it can still be inferred that unicellular Microcystis could not have formed such large colonies $(500 \mu \mathrm{m})$ in 10 days. Thus, the appearance of $M$. novacekii-like colonies was not generated by cell growth, but from morphological changes of the existing M. aeruginosa colonies.

It was proposed that algal cell size is useful for the dis- crimination of Microcystis morphospecies (Desikachary, 1959; Komárek, 1991). We also analysed cell size of both $M$. aeruginosa and $M$. novacekii-like colonies in our experiment (Tab. 3), but the result showed that the cell size of them was similar. This result also supported the conclusion that the appearance of $M$. novacekii-like colonies could be due to morphological changes in the existing $M$. aeruginosa colonies.

By using molecular tools (16S rDNA, 16S-23S ITS and $c p c \mathrm{BA}-\mathrm{IGS}$ ), there were stronger evidences to claim that the original $M$ aeruginosa colonies isolated from Lake Taihu and the later M. novacekii-like colonies in our cultures were the same genospecies. Even though, the similarity of $16 \mathrm{~S}$ rDNA sequences cannot be used to prove that the two Microcystis were actually the same species

Tab. 3. Colony characteristics of cultured Microcystis morphotypes.

\begin{tabular}{|c|c|}
\hline Morphotypes & Colony characteristics \\
\hline M. aeruginosa & $\begin{array}{l}\text { Colonies are irregularly branched or reticulated, varying greatly in size }(500-1200 \mu \mathrm{m}) \text {. In Lake Taihu, can be as small } \\
\text { as } 70 \mu \mathrm{m} \text {. Mucilage is invisible without treatment. Cells are somewhat densely and spherical. The cell diameter is } 1.7 \\
5.9 \mu \mathrm{m} \text {, and the average diameter is } 3.3 \mu \mathrm{m} \text {. (Fig. 1a) }\end{array}$ \\
\hline Intermediate morph & $\begin{array}{l}\text { Colonies }(160-1400 \mu \mathrm{m}) \text { keep the framework of } M \text {. aeruginosa, contain some subcolonies that connected to each other } \\
\text { unobtrusively. The cell diameter is } 1.8-5.3 \mu \mathrm{m} \text {, and the average diameter is } 3.6 \mu \mathrm{m} \text {. (Fig. } 1 \mathrm{~b} \text { ) }\end{array}$ \\
\hline M. novacekii-like morph & $\begin{array}{l}\text { Colonies are composed of several or even hundreds of subcolonies, varying greatly in size }(60-1600 \mu \mathrm{m}) \text {. Cells are tightly } \\
\text { aggregated, later becoming soft. The cell diameter is } 1.9-5.6 \mu \mathrm{m} \text {, and the average diameter is } 3.5 \mu \mathrm{m} \text {. Margin of colony } \\
\text { is indistinct (Fig. 1c) }\end{array}$ \\
\hline
\end{tabular}

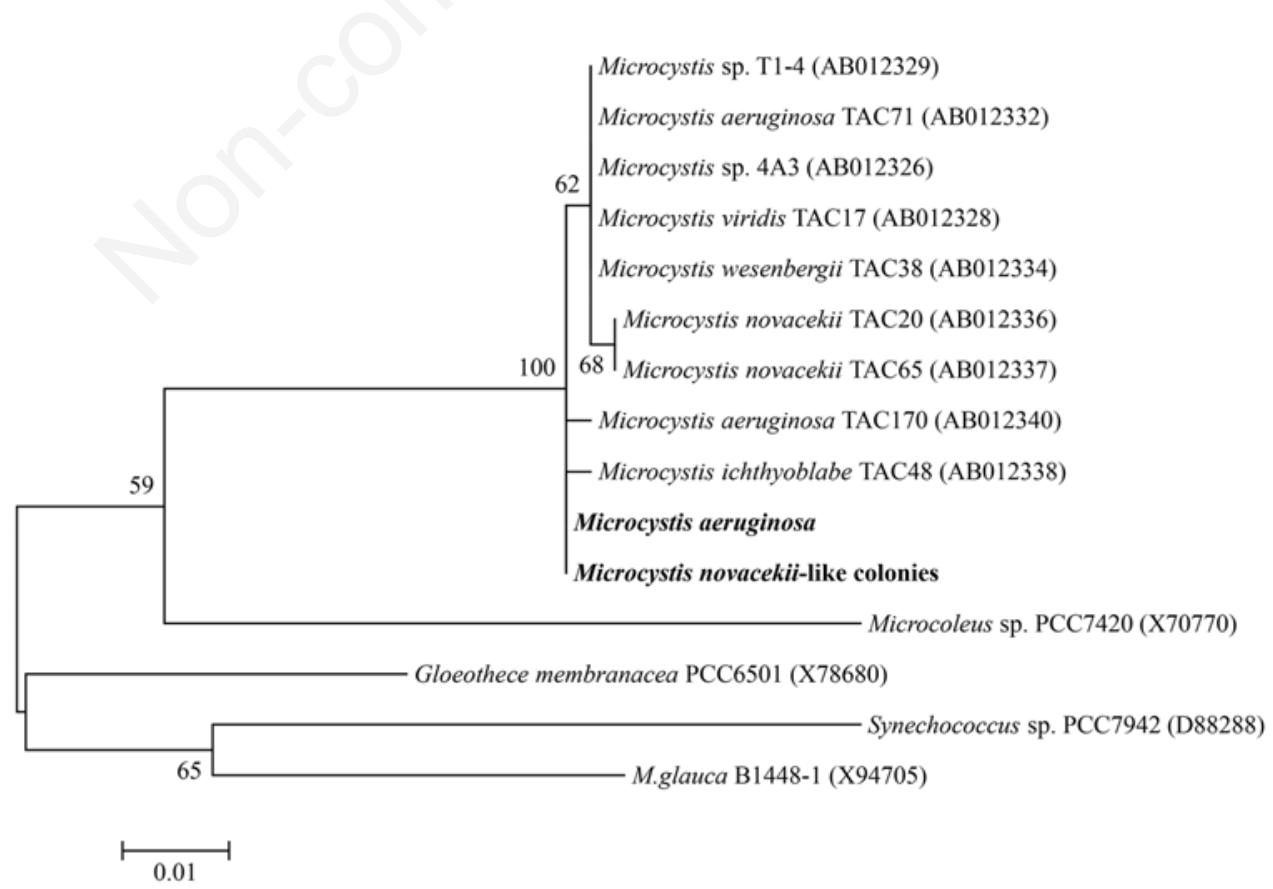

Fig. 5. Phylogenetic tree based on analysis of sequences of the $16 \mathrm{~S}$ rDNA. The bold characters indicated sequences of $M$. aeruginosa colonies at the beginning and M. novacekii-like colonies on the $60^{\text {th }}$ day in the current study. 
(Otsuka et al., 1998; Xu et al., 2014), the use of 16S-23S ITS and $c p c$ BA-IGS (Otten and Pearl, 2011; Tan et al., 2010) gave our results more robustness.

Both culture temperature $\left(25^{\circ} \mathrm{C}\right)$ and nutrient concentration in the current study was higher than that in Lake Taihu during sampling. These differences will affect colonial morphology of Microcystis (Li et al., 2013c: Yang and Kong, 2013). However, this will not affect the results of morphological changes of $M$. aeruginosa under culture condition because Microcystis grew well under this condition. Li et al. (2013a) measured the photosynthetic activity of Microcystis in Lake Taihu in the middle of autumn, and found that the $\alpha$ values were $0.085-0.27$, and the $\mathrm{ETR}_{\max }$ and $\mathrm{E}_{\mathrm{k}}$ values were 22.3-202.7 $\mu \mathrm{mol} \mathrm{m} \mathrm{m}^{-2} \mathrm{~s}^{-1}$ and 168.6$651.7 \mu \mathrm{mol} \mathrm{m} \mathrm{m}^{-2} \mathrm{~s}^{-1}$, respectively. The three characteristic parameters of the RLCs obtained in our study were similar to those in the above field investigation. The $\mathrm{F}_{\mathrm{v}} / \mathrm{F}_{\mathrm{m}}$ of $M i$ crocystis changed from 0.51 to 0.24 , which means the pho- tosynthetic efficiency of the algae on the $70^{\text {th }}$ day was lower. However, $\mathrm{F}_{\mathrm{v}} / \mathrm{F}_{\mathrm{m}}$ of Microcystis colonies in Lake Chaohu was as low as 0.25 (Wu et al., 2007). Therefore, even if $\mathrm{F}_{\mathrm{v}} / \mathrm{F}_{\mathrm{m}}$ of Microcystis colonies during the experiment decreased eventually was more similar to the colonies in the lake. With our study we proposed that M. aeruginosa colonies can change their morphological characteristics and turned into $M$. novacekii-like colonies, if cultivated under favourable growing conditions.

During the experiment, some soft and sponge-like colonies were also found. These colonies did not show the morphological characteristics of $M$. novacekii but had similar morphological characteristic of $M$. ichthyoblabe. However, the proportion of these colonies were much lower than that of $M$. novacekii-like colonies. It was reported that $M i$ crocystis colonies lost their characteristic features easily and disaggregated to single cells after long-term culture (Zhang et al., 2007). These M. ichthyoblabe-like colonies

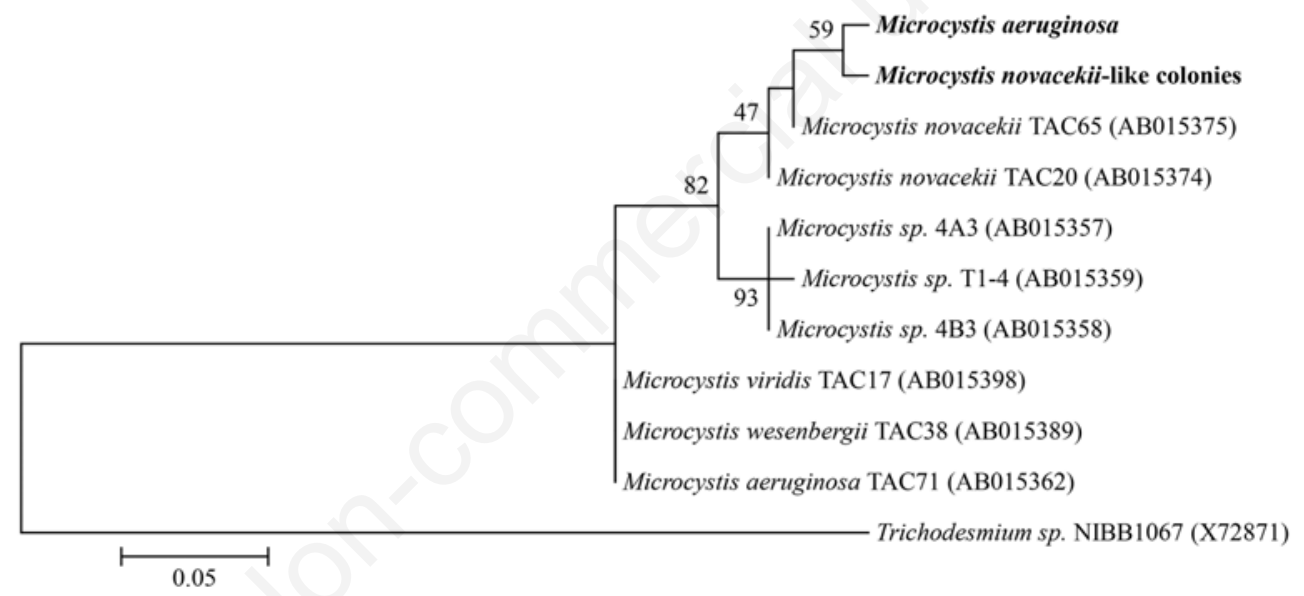

Fig. 6. Phylogenetic tree based on analysis of sequences of the 16S-23S ITS. The bold characters indicated sequences of $M$. aeruginosa colonies at the beginning and $M$. novacekii-like colonies on the $60^{\text {th }}$ day in the current study.

Tab. 4. Similarities between each Microcystis strain based on $c p c$ BA-IGS sequences.

\begin{tabular}{|c|c|c|c|c|c|c|c|c|c|}
\hline & 1 & 2 & 3 & 4 & 5 & 6 & 7 & 8 & \\
\hline & & & & & & & & & $\underline{1-M . \text { aeruginosa }}$ \\
\hline 2 & 99.2 & & & & & & & & $\underline{\text { 2-M. novacekii-like colonies }}$ \\
\hline 3 & 98.6 & 99.0 & & & & & & & 3-M. aeruginosa FACHB-936 \\
\hline 4 & 99.0 & 99.8 & 99.0 & & & & & & 4-M. aeruginosa FACHB-912 \\
\hline 5 & 95.0 & 94.9 & 94.6 & 94.8 & & & & & 5-M. novacekii UAM259 \\
\hline 6 & 97.6 & 98.0 & 98.5 & 97.9 & 93.5 & & & & 6-M. virids NIES-102 \\
\hline 7 & 99.0 & 99.8 & 99.0 & 100.0 & 94.6 & 98.4 & & & 7-M. sp. FACHB-574 \\
\hline 8 & 98.4 & 99.2 & 99.0 & 99.5 & 94.2 & 98.0 & 99.5 & & 8-M. aeruginosa UWOCC001 \\
\hline 9 & 98.1 & 97.4 & 96.9 & 97.2 & 96.3 & 96.0 & 97.2 & 96.5 & 9-M. novacekii UAM258 \\
\hline
\end{tabular}

The underlined characters are referred to the sequences of this study as $\mathrm{M}$. aeruginosa colonies at the beginning and $\mathrm{M}$. novacekii-like colonies on the $60^{\text {th }}$ day in the current study. 
would be due to disaggregation of $M$. aeruginosa colonies, and are the result of a well known phenomenon. Conversely, the $M$. novacekii-like colonies were formed by morphological changes of $M$. aeruginosa colonies, and this is a new interesting finding. We also analysed the proportion and the morphological characteristics of $M$. novacekii in Lake Taihu during our routine monitoring (Li et al., 2013b). M. novacekii appeared mainly from September to November when M. aeruginosa was the dominant Microcystis in Lake Taihu. The percentage of M. novacekii was very small (0.4-1.1\%) and the colony size was 50-400 $\mu \mathrm{m}$, both were much smaller than those of $M$. aeruginosa. $M i$ crocystis declined with biomass decrease and colony disaggregation during this time (Wang et al., 2012). The increase of space between subcolonies in $M$. novacekii made colonies more susceptible to disperse from wind shear under natural conditions. As a result, the composition of $M$. novacekii in Lake Taihu was fairly low and its colony size was much smaller than that under culture conditions without turbulence. A mass of small colonies found during this period (Li et al., 2013b) would be a circumstantial evidence for the disaggregation of Microcystis colonies. Moreover, M. novacekii and $M$. aeruginosa colonies appeared in the field at the same time when masses of small colonies were also found. Thus, we suggested that M. novacekii colonies were derived from the morphological changes of $M$. aeruginosa.

Otsuka et al., (2000) described three other morphotypes of $M$. novacekii in his study: i) colonies were discontinuously elongated; ii) colonies were lobated, elongated, or reticulated and resembled the morphotype of $M$. aeruginosa; and iii) colonies were less tight and nonhomogeneous or soft and homogeneous. Since M. novacekii can show several colony-forms corresponding to several morphospecies, such as $M$. aeruginosa-type or $M$. ichthyoblabe-type colonies, it is difficult to distinguish the M. novacekii morphospecies from others. In our study, we also found some colonies that were soft and homogeneous, but classified them as $M$. ichthyoblabe-like colonies based on morphospecies level taxonomy.

It was challenging to evaluate the seasonal succession of Microcystis morphospecies in the literature because the morphological criteria for Microcystis classification was confused. Colonies of different morphospecies may have similar morphological characteristics (Otsuka et al., 2000; Komárek and Komárková, 2002). Culture experiments also showed that Microcystis colonies sometimes varied their characteristics to resemble those of other morphospecies (Otsuka et al., 2000; Nguyen et al., 2012). Besides, taxonomy based on the morphological characteristics of Microcystis was not supported by phylogenetic analysis based on 16S rRNA, 16S-23S ITS sequences and $c p c \mathrm{BA}-$ IGS (Otsuka et al., 1999b; Nguyen et al., 2012). There is a limit to the botanical taxonomy of Microcystis, and the different morphospecies might be morphological variations of the same Microcystis genotype.

\section{CONCLUSIONS}

M. aeruginosa colonies collected in Lake Taihu were cultured under culture conditions. M. novacekii-like colonies were detected on the tenth day and its percentage of the population tended to increase until the $60^{\text {th }}$ day. As M. novacekii-like colonies increased, the percentage of M. aeruginosa decreased and almost disappeared by the end of the experiment. By using molecular tools (16S rDNA, 16S-23S ITS and cpcBA-IGS), there were stronger evidences to claim that the original $M$. aeruginosa colonies isolated from Lake Taihu and the later $M$. novacekii-like colonies in our cultures were the same species. We suggested that $M$. aeruginosa colonies consistently changed their colonial morphology to that of a typical M. novacekii.

\section{ACKNOWLEDGMENTS}

This study was sponsored by the National Natural Science Foundation of China (Grant 51409216), the Program on Furtherance of Scientific Research of Japan, Fundament C (15K00630) and the National Program on Key Basic Research Project of China (Grant no. 2012CB719804).

\section{REFERENCES}

Cao H, Kong F, Tan J, Zhang X, Tao Y, Yang Z, 2005. Recruitment of total phytoplankton, chlorophytes and cyanobacteria from lake sediments recorded by photosynthetic pigments in a large, shallow lake (Lake Taihu, China). Int. Rev. Hydrobiol. 90:347-357.

Cao H, Yang Z, 2010. Variation in colony size of Microcystis aeruginosa in a eutrophic lake during recruitment and bloom formation. J. Freshwater Ecol. 25:331-335.

Callieri C, Cronberg G, Stockner J, 2012. Freshwater picocyanobacteria: single cells, microcolonies and colonial forms, p. 229-271. In: B. Whitton (ed.), Ecology of Cyanobacteria II: their diversity in time and space. Springer.

Callieri C, Lami A, Bertoni R, 2011. Microcolony formation by single-cell Synechococcus strains as a fast response to UV radiation. Appl. Environ. Microb. 77:7533-7540.

Desikachary TV, 1959. Cyanophyta. Indian Council of Agricultural Research, New Delhi.

Imai H, Chang KH, Kusaba M, Nakano S, 2009. Temperaturedependent dominance of Microcystis (Cyanophyceae) species: M. aeruginosa and M. wesenbergii. J. Plankton Res. 31:171-178.

Jia X, Shi D, Shi M, Li R, Song L, Fang H, Yu G, Li X, Du G, 2011. Formation of cyanobacterial blooms in Lake Chaohu and the photosynthesis of dominant species hypothesis. Acta Ecologica Sinica 31:2968-2977.

Joung SH, Kim CJ, Ahn CY, Jang KY, Boo SM, Oh HM, 2006. Simple method for a cell count of the colonial cyanobacterium, Microcystis sp. J. Microbiol. 44:562-565.

Komárek J, 1991. A review of water-bloom forming Microcystis 
species, with regard to populations from Japan. Arch. Hydrobiol. Suppl. Algol. Stud. 64:115-127.

Komarek J, Anagnostidis K, 1999. Cyanoprokaryota. In:Ettl H, Gärtner G, Heynig H, Mollenhauer D, editors. Chroococcales. Gustav Fischer, Jena, p. 548.

Komárek J, Komárková J, 2002. Review of the European Microcystis morphospecies (Cyanoprokaryotes) from nature. Czech Phycol. 2:1-24.

Li D, Yang Z, Yu Y, Tang S, Zhang T, Zhou G, 2013a. [Photochemical vitality of cyanobacteria in Lake Taihu in spring and autumn season].[Article in Chinese with English abstract]. Acta Scientiae Circumstantiae 33:3053-3059.

Li M, Zhu W, Gao L, 2013b. Seasonal variations of morphospecies composition and colony size of Microcystis in a shallow hypertrophic lake (Lake Taihu, China). Fresen. Environ. Bull. 22:3474-3483.

Li M, Zhu W, Gao L, Lu L, 2013c. Changes in extracellular polysaccharide content and morphology of Microcystis aeruginosa at different specific growth rates. J. Appl. Phycol. 25:1023-1030.

Li M, Zhu W, Sun Q, 2014a. Solubilisation of mucilage induces changes in Microcystis colonial morphology. New Zeal. J. Mar. Fresh. 48:38-47.

Li M, Zhu W, Gao L, 2014b. Analysis of cell concentration, volume concentration, and colony size of Microcystis via laser particle analyzer. Environ. Manage. 53:947-958.

Neilan BA, Jacobs D, Goodman AE. 1995. Genetic diversity and phylogeny of toxic cyanobacteria determined by DNA polymorphisms within the phycocyanin locus. Appl. Environ. Microbiol. 61:3875-3883.

Nguyen VLA, Tanabe Y, Matsuura H, Kaya K, Watanabe MM, 2012. Morphological, biochemical and phylogenetic assessments of water-bloom-forming tropical morphospecies of Microcystis (Chroococcales, Cyanobacteria). Phycol. Res. 60:208-222.

Otsuka S, Suda S, Li R, Watanabe M, Oyaizu H, Matsumoto S, Watabanabe MM, 1998. 16S rDNA sequences and phylogenetic analyses of Microcystis strains with and without phycoerythrin. FEMS Microbiol. Lett. 164:119-124.

Otsuka S, Suda S, Li R, Watanabe M, Oyaizu H, Matsumoto S, Watabanabe MM, 1999a. Phylogenetic relationships between toxic and nontoxic strains of the genus Microcystis based on $16 \mathrm{~S}$ to $23 \mathrm{~S}$ internal transcribed spacer sequences. FEMS Microbiol. Lett. 172:15-21.

Otsuka S, Suda S, Li R, Watanabe M, Oyaizu H, Matsumoto S, Watanabe MM, 1999b. Characterization of morphospecies and strains of the genus Microcystis (Cyanobacteria) for a reconsideration of species classification. Phycol. Res. 47:189-197.

Otsuka S, Suda S, Li R, Matsumato S, Watanabe MM, 2000. Morphological variability of colonies of Microcystis morphospecies in culture. J. Gen. Appl. Microbiol. 46:39-50.

Ozawa K, Fujioka H, Muranaka M, Yokoyama A, Katagami Y, Homma T, Ishikawa K, Tsujimura S, Kumagai M, Watanabe $\mathrm{MF}, 2005$. Spatial distribution and temporal variation of $\mathrm{Mi}$ crocystis species composition and microcystin concentration in Lake Biwa. Environ. Toxicol. 20:270-276.

Otten TG, Paerl HW, 2011. Phylogenetic inference of colony isolates comprising seasonal Microcystis blooms in Lake Taihu, China. Microbial Ecol. 62:907-918.
Paerl HW, Fulton RS, Moisander PH, Dyble J, 2001. Harmful freshwater algal blooms, with an emphasis on cyanobacteria. Sci. World J. 1:76-113.

Park HD, Watanabe MF, Harada KI, Suzuki M, Hayashi H, Okino T, 1993. Seasonal variations of Microcystis species and toxic heptapeptide microcystins in Lake Suwa. Environ. Toxicol. Water Qual. 8:425-435.

Prescott GW, 1948. Objectionable algae with reference to the killing of fish and other animals. Hydrobiologia 1:1-13.

Ralph PJ, and Gademann R. 2005. Rapid light curves: a powerful tool to assess photosynthetic activity. Aquat. Bot. 82:222-237.

Schreiber U. 2004. Pulse-amplitude-modulation (PAM) fluorometry and saturation pulse method, p. 279-319. In: G.C. Papageorgiou and Govindjee (eds.), Chlorophyll a fluorescence. Kluwer Academic Publ.

Sivonen K, Jones G, 1999. Toxic Cyanobacteria in water: a guide to their public health consequence, monitoring and management. CRC Press, Boca Raton: 440 pp.

Shen H, Niu Y, Xie P, Tao M, Yang X, 2011. Morphological and physiological changes in Microcystis aeruginosa as a result of interactions with heterotrophic bacteria. Freshwater Biol. 56:1065-1080.

Tamura K, Peterson D, Peterson N, Stecher G, Nei M, Kumar S, 2011. MEGA5: molecular evolutionary genetics analysis using maximum likelihood, evolutionary distance, and maximum parsimony methods. Mol. Biol. Evol. 28:2731-2739.

Tan W, Liu Y, Wu Z, Lin S, Yu G, Yu B, Li R, 2010. cpcBA-IGS as an effective marker to characterize Microcystis wesenbergii (Komárek) Komárek in Kondrateva (cyanobacteria). Harmful Algae 9:607-612.

Watanabe MF, Oishi S, Harada KI, Matsuura K, Kawai H, Suzuki M, 1988. Toxins contained in Microcystis species of cyanobacteria (blue-green algae). Toxicon 26:1017-1025.

Watanabe MF, Harada K, Matsuura K, Oishi S, Watanabe Y, Suzuki M,1989. Heptapeptide toxins contained in natural samples of Microcystis species. Toxic. Assess. 4:487-497.

Watanabe M, 1996. Isolation, cultivation and classification of bloom-forming Microcystis in Japan, pp. 13-34. In: M.F. Watanabe, K. Harada, W.W. Carmichael and H. Fujiki (eds.), Toxic Microcystis. CRC Press.

Wang Z, Li G, Li G, Li D, 2012. The decline process and major pathways of Microcystis bloom in Taihu Lake, China. Chin. J. Oceanol. Limnol. 30:37-46.

Wu X, Kong F, Cao H, Zhang M, Liu G, Zhao Q, 2007. [In situ study on the photochemical vitality of overwinring phytoplankton].[Article in Chinese with English abstract]. J. Lake Sci. 19:139-145.

Wu Z, Gan N, Song L, 2007. Genetic diversity: Geographical distribution and toxin profiles of Microcystis strains (Cyanobacteria) in China. J. Integr. Plant Biol. 49:262-269.

Xu S, Peng Q, Li M, 2014. Morphospecies and genospecies of Microcystis during blooms in eutrophic Lake Taihu (China) in autumn. Biochem. Syst. Ecol. 57:322-327.

Yamamoto Y, Nakahara H, 2009. Seasonal variations in the morphology of bloom-forming cyanobacteria in a eutrophic pond. Limnology 10:185-193.

Yang Z, Kong F, Cao H, Shi X, 2005. Observation on colony formation of Microcystis aeruginosa induced by filtered lake water under laboratory conditions. Ann. Limnol.-Int. J. Lim. 41:169-173. 
Yang Z, Kong F, Shi X, Zhang M, Xing P, Cao H, 2008. Changes in the morphology and polysaccharide content of Microcystis aeruginosa (cyanobacteria) during flagellate grazing. J. Phycol. 44:716-720.

Yang Z, Kong F, 2012. Formation of large colonies: a defense mechanism of Microcystis aeruginosa under continuous grazing pressure by flagellate Ochromonas sp. J. Limnol. 71:61-66

Yang Z, Kong F, 2013. Abiotic factors in colony formation: ef- fects of nutrition and light on extracellular polysaccharide production and cell aggregates of Microcystis aeruginosa. Chin. J. Oceanol. Limnol. 31:796-802.

Zhang M, Kong F, Tan X, Yang Z, Cao H, Xing P, 2007. Biochemical, morphological, and genetic variations in Microcystis aeruginosa due to colony disaggregation. World J. Microb. Biot. 23:663-670.

Zhou J, Bruns MA, Tiedje JM, 1996. DNA recovery from solis of diverse composition. Appl. Environ. Microb. 62:316-322. 